\title{
The Psycho-Sociological Perspective on Civilization: Insights from Malik Bennabi Theory
}

\author{
EL-MEKDAD SHEHAB \& ABDELKOUDDOUS SMATI ${ }^{1}$
}

\begin{abstract}
Throughout history, civilizations have served as the highest level of human progress, and just like countries, empires or societies, they have always been prone to rise and fall. As a result, attempts to understand their dynamics, formation, and decline have been significantly important for sociologists, politicians, anthropologists and historians, both recently and in the past. One of those was the Islamic scholar Abdurrahman Ibn Khaldun, who tried in his book "Muqaddimah" to explain the rise and fall of states, and despite the uniqueness and distinction of his proposition, Ibn Khaldun's contributions confined to the temporal-spatial context that Ibn Khaldun tried to explore, and his theory has not been developed to explain the civilizational dynamics, especially the Islamic civilization. This matter has been noticed by Malik Bennabi, who succeeded in making remarkably systematic contributions to the topic. Through relying on the psycho-sociological essence of Ibn Khaldun's theory. So that, this paper attempts to present some insights from psycho-sociological approach of Malik Bennabi in explaining the rise and fall of civilizations, compared to some Western theories that have addressed the relative topics.
\end{abstract}

Keywords: civilization dynamics, power dynamics, Ibn Khaldun, Malik Bennabi, sociopolitical transformations.

Change may be the most unanimously recognized human value, within his limited age a human being experiences the transformation of all things around him from feelings, behaviour, demography, architecture, power relations, to socio-politics, and the latter has the deepest impact. The importance of socio-political transformations consists in the amount of change they cause to the course of history, as the socio-political transformations affect the culture of people as much as they affect the structure of societies and state policies. Therefore, no wonder that many political scientists, historians, sociologists and civilization scholars are interested in understanding how a human group rises to the peak of power, and how it might lose such power totally or how such power might gradually decline, and if there is any governing patterns that can explain that cyclical process of rise and fall. Thus, they made numerous analytical contributions, varying in the scope, from nations, states, empires, to civilizations, as well as varying in their interpretations, whether they depend on material, moral factors or both (Ferguson 2012, Spengler 2012, Toynbee 1939, Goldman 2011, Kennedy 1988, Acemoglu \& Robinson 2013, Diamond 2011, Bremmer 2007). However, the only consensus they have extracted from history is that no single power can remain in an everlasting rise, and that it must fall afterwards (Ferguson 2010). One of the most important

${ }^{1}$ Elmekdad Shehab* (corresponding author), M.A., a Research Assistant at Gulf Studies Center, and $\mathrm{Ph}$. D. candidate in Gulf Studies Dept., College of Arts and Science, Qatar University, 2713, DOHA, Qatar. Email: eshehab@qu.edu.qa; Abdelkouddous Smati, M.A candidate in Political Science and International Relations, Dept. of Political Science, Faculty of Law and Political Science, University of Mohamed Lamine Débaghine-Sétif 2, 19200 SETIF, Algeria. Email: smatiabdelkouddous@gmail.com

$$
\text { https://doi.org/10.24035/ijit.19.2021.192 }
$$


contributions was Ibn Khaldun's theory interpreting the rise and fall of states, which despite its uniqueness, but its explanatory capacity has been confined to the cases studied and interpreted by Ibn Khaldun, and rarely social scientists depend on his ideas to explore other social contexts (Alatas 2013, 2015 ), except the Algerian scholar Malik Bennabi who benefited from the psychosociological essence of Ibn Khaldun's theory, and succeeded in making remarkably systematic contributions to the topic which allowed him to provide a comprehensive model explaining rise and fall of civilizations. Therefore, this paper seeks to shed the light on some insights of the psychosociological approach of Malik Bennabi and clarify its roots as derived from Ibn Khaldun, compared to modern Western literature in the relative topics.

In order to identify the contributions of scholars and researchers with respect to studying the socio-political transformations, and place the model of Malik Bennabi in this literature, this paper will be divided into two parts. The first part will discuss the most important literature that has reviewed the rise and fall of powers in a modern Western perspective in order to identify the main reasons leading to the steady movement of rise and fall, and the second part will discuss the psycho-sociological approach adopted by Malik Bennabi to follow the same path of Ibn Khaldun.

\section{Literature Discussing the Rise and Fall of Powers in the Modern Western Literature}

The Western literature on the rise and fall of powers can be divided into several types according to their analytical units, as well as the dimension that it focused on as part of its interpretation of this movement. In terms of analytical unit, there are theories that have been concerned with interpreting the rise and fall of civilizations (Ferguson 2012, Spengler 2012, Toynbee 1939, Goldman 2011) However, others were interested in interpreting the rise and fall of empires or superpowers( Kennedy 2017 ) while some focused on explaining the rise and fall of societies or nations (Acemoglu \& Robinson 2013, Diamond 2011, Bremmer 2007) These theories also have differed in the dimension they focused on to explain this circular movement of rise and fall as follows:

\section{Cultural Dimension}

The German philosopher Max Weber's book "Protestantism and the Spirit of Capitalism" is one of the most important attempts to explain socio-economical transformations considering the cultural dimension. Max Weber argues that the Protestant Creed- especially in its Calvinist version - had significantly contributed, through the creed of Predestination, to the emergence of Capitalism. Predestination creed is that every person's punishment or delight has been predetermined. A person's success, delight or wealth in the worldly life is a sign that God loves him and that he is one of those predestined to be in delight. Therefore, a Protestant Christian had to strive to prove his destiny in the worldly life, leading to the emergence of a new human psyche that seeks wealth for the sake of wealth. As such, wealth has gradually accumulated, paving the way to the emergence of Capitalism (Weber 2011:173). Although Max Weber had used the cultural dimension in explaining Capitalism as a socio-economic phenomenon, Neil Ferguson, a century later, reached the same conclusion in his book "Civilization: The West and the Rest.", stating that Christianity was one of the most important reasons for the prevalence of the Western civilization over other civilizations during the nineteenth and twentieth centuries (Ferguson 2012: 510)

\section{Demographic Dimension}

Based on the works of the German philosopher, Oswald Spengler, Goldman wrote his book "How Civilizations Die" focusing on another dimension, i.e. the demographic dimension, while attributing 
its essence to cultural factors. Goldman believes that the demographic dimension will determine the fate of human civilization during the twenty-first century, saying:

The world's population will fall by as much as a fifth between the middle and the end of the twenty-first century, by far the worst decline in human history for the first time in history, the birth rate of the whole developed world is well below replacement, and a significant part of it has passed the demographic point of no return (Goldman 2011:113)

Goldman believes that the modernization movement coming in the form of change in the structure of traditional communities, such as the spread of education and urbanization, caused this sharp decline in birth rates. He also pointed out an important factor that impact the lives of nations and communities, i.e. the relationship between religiosity and fertility, with fertility increasing as a result of higher religiosity, and vice versa. This is evident by the fact that countries with the lowest rates of fertility are the countries of Eastern Europe, which were under the control of Atheistic Communism. On the contrary, the highest fertility rates in the developed world are in America and Israel, the most religious countries (Goldman 2011:113)

In a similar vein, Buchanan, a former adviser to three American presidents, Rixson, Ford and Reagan, warned against a breakdown of the basic Judeo-Christian values of Western civilization beginning in the mid-20th century as the Western civilization had been penetrated by other value systems as a result of immigration flows and refugee influxes transmitting cultures that are foreign to the American Community (Buchanan 2002). As such, he prefaced his book entitled "Suicide of a Superpower: Will America Survive to 2025?" Saying: "when faith dies, the culture dies, the civilization dies, and the people begin to die"(Buchanan 2012)

\section{Leadership Dimension}

Unlike Weber, Goldman, Ferguson and Buchanan, Arnold Toynbee, in his famous theory of "Challenge and Response" rejected the attribution of the rise and fall of nations to the circular movement based on the culture, suggesting another factor, i.e. the ability of the communities to respond to the challenges they face in the course of their development. As such, he agreed with those mentioned above by referring to the internal factors as the most important in interpreting the development of societies. For Toynbee, "civilisations die by internal suicide, but not external assassination". This is when leadership of these communities fails to respond to the challenges they face internally, whether they come in the form of environmental, economic, military or cultural challenges (Toynbee 1939: 23).

\section{Material Dimension (Economic and Military)}

About half a century after the emergence of Toynbee had thesis, Paul Kennedy published his famous book "The Rise and fall of the Great Powers" in 1987... Because Kennedy belongs to realism in understanding international politics, his thesis mainly focused on interpreting the rise and fall of greatest power on material factors, i.e. Economic and military factors. For him, there is recurring narrative in history that great powers, in their quest to maximize their influence and economic power, seek further spreading and domination, followed by increasing in expenditure on defence and military activities. Which ultimately puts them in dilemma that leads to the depletion and degradation of these great power by other rising powers that can achieve that difficult balance between economic requirements and military expenditure (Kennedy 2017:138)

It's worth noting that Paul Kennedy's book appeared shortly before end of the cold war and the defeat of the Soviet Union. It was an important event in American cultural community, which was concerned with the future of USA. Thereafter, during what is known as "War on Terrorism" at the

$$
\text { https://doi.org/10.24035/ijit.19.2021.192 }
$$


beginning of the new millennium, and China's increasing presence on the global economic scene, the ideas of the book were re-inspired, and its arguments and assumption were subject to debate and criticism by the American intellectual elite.

\section{Institutional Dimension}

In 2013, James Robinson and Daron Acemoglu published their book "Why Nations Fail?" (Acemoglu \& Robinson 2013) Both authors, who come from an economic background, wondered about the reason behind a nation being poor and powerless, while other nations enjoy welfare, prosperity? To answer this question, the two authors made a comparative historical analysis of a number of successful and unsuccessful countries, focusing on tracing the emergence of state institutions in these countries. Therefore, they classified these institutions based on the relationship between their elite and community into two types (exclusive institutions - and inclusive institutions). Exclusive institutions mean institutions closed to their elite, working according to their will and for their own benefit while inclusive institutions grow from within community and work for its benefit. Their answer on such question was as follows: The difference between successful and unsuccessful countries lies in the historical way in which the institutions of governance and administration were built in these countries rather than being based on any natural, geographical, climatic, customary or even cultural factor! The success of any country is attributable to the inclusive development of its institutions while the institutions of underdeveloped countries have exclusively developed.

\section{Environmental Dimension}

On the contrary of what have been reviewed before about the explanations of factors contributed in the rise and fall of the powers, approximately all of them focused on the internal factors like the institutions, or the political, economic, cultural, or demographical factors, for these factors come from within the society of such powers. However, that does not necessarily mean the absence of other exterior factors that could have an impact on this process. In his book How Societies Choose to Fail or Succeed (Diamond 2011:5), Jared Dimond presented another circular aspect that could explain the rise and fall of societies depending on the environmental dimension and the climatic factors. Diamond believes the uncontrolled usage of the natural resources by the societies that mainly depend on such resources might result in an environmental frailty and consequently such societies will be extremely and badly affected by the environmental changes and disasters. That could in return cause the weakness of such societies and they could be easily militarily invaded by neighbouring enemies who are usually ready for such action.

In summary, the topic of the rise and fall of powers - either nations, empires, or civilizations earned a great interest in the modern Western literature. Such literature discussed various factors to explain this phenomenon and tried to figure it out from many aspects (as seen on figure 1) either internal or exterior. Also, whether it depends on material factors (economics, military, environmental, institutional), or immaterial ones (culture, religion, leadership, demography). Despite all such efforts, all these involved two problems:

1. It could not combine all the factors in a single approach. In each of the previous studies some factors were deliberately either ignored or highlighted, which makes them contradict.

2. As a result of the previous partial addressing, such literature could not provide a single coherent narration starting from the rise of such powers, then its development and finally its deterioration. In other words, it could not explain how a certain idea or worldview could evolve socially and politically into a strong state or civilization.

https://doi.org/10.24035/ijit.19.2021.192 
This means the need for an approach that could involve the entire material, immaterial factors in explaining the rise and fall of powers phenomena, this is the gap the research claims that Ibn Khaldun's theory and its developments by the Algerian philosopher Malik Bennabi, could cover.

\begin{tabular}{|l|l|l|}
\hline \multicolumn{1}{|c|}{$\begin{array}{c}\text { The Factor Contributing to the Rise and } \\
\text { Fall }\end{array}$} & \multicolumn{1}{|c|}{ Thesis Owner } & \multicolumn{1}{c|}{ Unite of Analysis } \\
\hline Cultural factor & Max Weber & Civilizations \\
\hline Leadership factor & Arnold Toynbee & Civilizations \\
\hline Economic-military factor & Paul Kennedy & Superpowers - empires \\
\hline Institutional factor & James Robinson & Nations \\
\hline Demographic factor & David Goldman & Nations - Civilizations \\
\hline Environmental and climatic factor & Jared Dimond & Nations - societies \\
\hline
\end{tabular}

Table (1) Summary of Modern Western Literature in Explaining the Reasons for the Rise and Fall of Powers

\section{Psycho-Sociological Approach of Malik Bennabi and Ibn Khaldun}

The Muslim scholar Abdul Rahman Ibn Khaldun (1332-1406D), one of the most influential scholars in the fields of society and politics in history, his thoughts earned a great interest from scholars and researchers in various social and human fields. However, the use of Ibn Khaldun's theory in explaining the political or social transformations (i.e. the rise and fall of powers) has remained scarce.[1] Perhaps the most notable of these attempts is the work of the Malaysian scholar, Sayyid Farid Al-Attas, whose research focused for more of twenty years on the contemporary use of the ideas of Ibn Khaldun, culminating such works with his last two books in 2013 and 2014, "Ibn Khaldun" and "Applying Ibn Khaldun: The Recovery of a Lost Tradition in Sociology" respectively (Alatas 2013, 2015). Al-Attas assumes in both books that Ibn Khaldun's project basically examines the "historical sociology of state formation", i.e., how the state and society develop over time. He also believes that Ibn Khaldun's theory can be used recently in the analysis of societies whose social structure is still based on the tribe in one way or another, or where the role of religion is still active.

For example, in his book "Applying Ibn Khaldun", he used the ideas of Ibn Khaldun to explain the state formation over five case studies- the Ottoman and Safavid Empire, Iran, Saudi Arabia, and modern Syria. Despite this advance attempt by Farid Al-Attas, which varied between the study of ancient and modern powers, Al-Attas did not deviate from the classical thinking style when using Ibn Khaldun thoughts. For instance, when Al-Attas observed that Ibn Khaldun's theory lacks economic dimensions, he transferred some Marxist ideas on the "mode of production" to interpret the cases studied by him, especially the Asian societies. In fact, by using Ibn Khaldun's thoughts as such, he has not introduced a new approach to expand Ibn Khaldun's scope. He either used Ibn Khaldun's thoughts in the same old classical way that could not free him from his limited interpretative scope, or completely deviated from such scope, leaving nothing from Ibn Khaldun's thoughts (Alatas 2015:127). this makes us wonder about the difference between Ibn Khaldun's classical understanding and the new understanding, or what could be called "the neo-khaldunian approach" introduced by Malik Bennabi? The difference lies in understanding the essence of Ibn Khaldun's contributions as a "psycho-sociological approach". This becomes clear if we highlight the key idea in Ibn Khaldun's theory on explaining the rise and fall of states - i.e. bedouinism and urbanization cycle. For the psycho-social perspective when Ibn Khaldun spoke about the bedouinism and urbanization as the basis for the rises and falls of political powers, he referred to

$$
\text { https://doi.org/10.24035/ijit.19.2021.192 }
$$


them as two different environments leading to different psychic and personality attributes. His basic analytical unit was "human psyche and lifestyle." For Ibn Khaldun, Bedouinism means hardness of life, self-reliance, seriousness, ability to take risks and ease of movement while the urbanizational environment means the welfare of life, stability, lack of patience, and dependency. Ibn Khaldun says in his Muqaddimah entitled: Bedouins are more disposed to courage than sedentary people:

The reason for this is that sedentary people have become used to laziness and ease. They are sunk in well-being and luxury. They have entrusted defence of their property and their lives to the governor and ruler who rules them, and to the militia which has the task of guarding them. They find full assurance of safety in the walls that surround them, and the fortifications that protect them. No noise disturbs them, and no hunting occupies them. They are carefree and trusting and have ceased to carry weapons. Successive generations have grown up in this way of life. They have become like women and children, who depend upon the master of the house. Eventually, this has come to be a quality of character that replaces natural (disposition). (Khaldun 2005: 94)

Ibn Khaldun said that the main factor controlling the movement of the rise and fall of states is the psyche of its members. The pattern of life and its psychological and social impact is the basic analytical unit that Ibn Khaldun meant. This is what is grasped by the Algerian philosopher Malik Bennabi to develop his model of the cycle of civilization, based on the importance of the religious idea and its psychosocial impact on human personality and the structure of society.

It is time to say that in the time of Ibn Khaldun, it was difficult to acquire Bedouin characteristics outside the Bedouin environment, and it was difficult to acquire and civilized characteristics outside the urban environment, but this does not mean that this is impossible. Social and moral education can take place in any environment. The decisive factor in the rise and decline of civilization is man's psyche, will and personality, rather than the nature of the environment. According to Ibn Khaldun, the environment nature is only as much significant based on the extent to which it impacts the psyche of both the individual and the community.

The difference between classical and new understanding of Ibn Khaldun's theory can be summarized as follows:

\begin{tabular}{|l|l|l|}
\hline $\begin{array}{l}\text { The Main Points } \\
\text { of Difference }\end{array}$ & $\begin{array}{c}\text { The Classical Understanding of } \\
\text { Ibn Khaldun's Theory }\end{array}$ & \multicolumn{1}{|c|}{ The New Understanding of Ibn Khaldun's Theory } \\
\hline $\begin{array}{l}\text { The nature of Ibn } \\
\text { Khaldun's theory }\end{array}$ & $\begin{array}{l}\text { Ibn Khaldun's theory is viewed } \\
\text { as a materialistic approach }\end{array}$ & $\begin{array}{l}\text { Ibn Khaldun's theory is viewed as a psycho- } \\
\text { sociological approach }\end{array}$ \\
\hline $\begin{array}{l}\text { Interpretation of } \\
\text { the circle of } \\
\text { Bedouinism and } \\
\text { urbanization }\end{array}$ & $\begin{array}{l}\text { It is a conflict between the } \\
\text { Bedouin and the urban }\end{array}$ & $\begin{array}{l}\text { It is a conflict between the "Bedouin psyche" with } \\
\text { its lifestyle, morals and personality on one hand, } \\
\text { and the "urban psyche" with its lifestyle, morals } \\
\text { and personality on the other hand. }\end{array}$ \\
\hline $\begin{array}{l}\text { The main } \\
\text { analysis unit }\end{array}$ & $\begin{array}{l}\text { Tribal and other forms of social } \\
\text { solidarity. }\end{array}$ & $\begin{array}{l}\text { The psycho-sociological impact of the religious idea } \\
\text { on the psyche of the individual and the network of } \\
\text { community relationships. }\end{array}$ \\
\hline
\end{tabular}

Table (2) Comparison between the Classical and New Understanding of bin Khaldun's Theory 


\section{Psycho-Sociological Approach According to Malik Bennabi:}

After absorbing the psycho-sociological essence of Khaldun and studying the impacts of the religious idea on the personality of the individual and the structure of society. the Algerian scholar the Malik Bennabi (1905-1973) was able to go beyond the thought of Ibn Khaldun, to the "civilization" as most progress political unit. Moreover, Malik Bennabi's approach was different from the modern Western literature, which discussed the rise and fall of powers because he is not limited to one dimension, material or moral, however, Malik Bennabi was able to assimilate all these elements in one model. Malik Bennabi was greatly affected by Ibn Khaldun, and the similarities can be seen in the following points:

1. Both believed in the circular movement of history, in the rise and fall of political powers and viewed them as inevitable and unavoidable.

2. Both emphasized the essential role of the religious ideas in socio-political transformation.

3. Both referred to the psycho-sociological impacts of this religious idea in the creation and development of social structures. It was expressed by Ibn Khaldun through the term "Asabiyyah" or social solidarity and was expressed by Malik Bennabi with the term "social network".

Malik Bennabi did not differ from Ibn Khaldun except in one point, namely, that he discovered an analytical unit beyond what is covered by Ibn Khaldun, i.e. civilization. According to Malik Bennabi, civilization is the accumulation of human, material and moral factors. In addition, the emergence or demise of civilizations is more sophisticated and complex than the rise and fall of the states; this is the point upon which Ibn Khaldun concluded his research.

In conclusion: Malik Bennabi developed the ideas of Ibn Khaldun, based on the psychosociological lens, which indicate the impact of religious idea in the psyche of individuals and then in the structure of society, paving the way for the emergence of a new society representing that religious idea. This birth of the new society is the first point at the beginning of any new civilization according to Malik Bin Nabi.

\section{The Three Big Ideas of Malik Bennabi}

In this section, the theoretical framework developed by Malik Bennabi will be presented based on three key concepts presented in his thesis on the rise and fall of civilizations: the concept of "the religious idea which combinate of the civilization factors", the concept of "the social relations network which combinate the realms of civilization" and the concept of "Civilization cycle which relfects the stages of civilizations".

\section{Religious Idea and Elements of Civilization}

Malik Bennabi considered civilization the ultimate human social development and the goal of the social movement in history. He defined it in his work in many aspects (Benlahcene 2011). For its functional aspect, Malik Bennabi considered civilization "the set of moral and material conditions that enable a particular society to provide every individual in society, in each stage of its growth from childhood to old age, with the necessary assistance for it in this stage." For its structural aspect, he considered that civilization develops the installation of three elements that exist naturally in all societies, these factors are: man, soil and time, as shown in the following equation: (Bennabi 1981: 45) 


\section{Religion \\ Man $\mathbf{4}$ Soil $\mathbf{4}$ Time}

Figure (1) the Equation of Civilization from the Perspective of Malik Bennabi

The element of man means the will of that man, his mind, behaviour and feeling, the element of soil is all the material, terrestrial and natural factors that surrounds that man, the factor of time is the temporal context, when that man lives, whose value varies depending on production and the impact of man. According to Malik Bennabi, time "passes through the cities, nourishing its activity with its eternal power or forcing them to sleep due to hours which go in vain. It flows both in the land of every people and the field of every individual with an overwhelming number of hours which do not decrease. However, it becomes ((wealth)) in area, and it turns into nothing in another area. It goes during the life, providing history with those values granted due to the work done by the time" (Bennabi 1981: 139)

However, these three factors are not combined and collected to form civilization automatically, but they need a catalyst contributing to melting, blending them together and directing them to form civilization. Accordingly, this composite is the religious idea. Malik Bennabi believes that "the strength of the composition of civilization factors is inherent in the core of religion (Bennabi 1981: 139)

Malik Bennabi's religious idea is any worldview that governs man thought, directing its gaze toward a wider horizon, controlling human vitality and dedicating it to civilization (Bennabi 1991: 110) In his view, it is every idea that offers a hidden deity and a divine promise, from monotheistic Islam to paganism (Bennabi 1987: 30). Without such religious idea, these three elements remain stagnant and stacked and do not play a role in history. Hence, Malik Bennabi decides that the starting point for understanding the evolution of society in Islamic civilization should be the religious idea.

Malik Bennabi says: "It is known that the Arabian Peninsula, for example was, before the descent of the Quran, merely Bedouin people living in an infertile desert, whose time goes in vain and who do not benefit from such time, so the three elements: Man, dust and time are stagnant and idle, or more properly, they are stacked with no role in history, even if the spirit manifested in the Cave of Hira - as demonstrated in the Holy Valley, or the water of Jordan - Among these three elements, a new civilization had emerged"(Binanbi 1981: 45)

According to Malik Bennabi, the birth of civilization is in two stages. The first stage is when the religious or worldview deepened in the soul through the psycho-social impact of this idea in modifying the behaviour, feeling and morals of its adherents, which leads to the emergence of a new social network. The second stage is when such idea and its new network expresses itself in common collective behaviour in the history (e.g., the migration incident in Islamic civilization). Hence, Malik Bennabi believes that Islamic civilization was more unique than Western Christian civilization in that the recording of the idea in the soul and history are temporarily close, he says:

"If the Islamic civilization brought together the births at the same time, it is due to the emptiness found by the Islamic idea in the Arab Virgin soul, in which no culture was established, nor a previous religion, so the coast is clear. The chance of Christian civilization was not like the Islamic civilization in its impact on its people's souls and its environment. Christian civilization was born in an environment containing a mixture of religions, Hebrew, Romanian and Greek cultures, so it was not allowed to deepen in the hearts of people during the cultural intellectual hustle to effectively affect them. It could not work only when it reached the environment of the Germanic paradise in northern Europe, where it found the empty souls, managing and bringing the effective spirit to them, which rushed to form its role in the historic series"(Bennabi 1981: 55)

https://doi.org/10.24035/ijit.19.2021.192 
The psychological change caused by the religious idea in the souls of individuals and then in society is the mechanism by which a new civilization emerges. Therefore, Malik Bennabi believes that every social change is due primarily to change in the human soul first, based on the words of God Almighty, who says: "Allah does not change the condition of a people unless they change what is in themselves." [surah Ar Ra'd 13/11] He states that: The way to civilization is available as long as there is a religious idea that consists of the three elements: Man, soil, and time, to form a mass called in history "civilization"(Bennabi 1981: 57).

\section{The Network of Social Relations and Realms of Civilization}

Malik Bennabi thought that the moment of recording the religious idea in history is the moment when the new society is born, and it is itself the moment when the new civilization emerges. Malik Bennabi then developed the " network of social relations" concept which explains how a certain religious idea can create a new society.

According to Malik Bennabi, the new society created when new system of relations between members of shared culture (Bennabi 1986: 14). This human community acquires the status of (society) only when it initiates the movement, i.e. when it begins to change itself in order to reach its goal. The static communities - according to Malik Bennabi - live in the pre-civilization, because they are not wedded to one goal, the movement and the unity of purpose are two conditions for the definition of society according to Malik Bennabi.

As civilization was made up of three elements combined and blended by the religious idea, the history according to Malik Bennabi is the accumulated effect of three realms: the realm of ideas, the realm of people, and the realm of things. These realms accumulate only through the necessary social relations (Social network). "These three realms do not work separately, but they work jointly. The form of work is in line with ideological models of (the realm of ideas), which are carried out by means of (the realm of things), for a goal determined by (the realm of people)," says (Bennabi 1986: 25)

He says "Society is not just a number of individuals; it is the participation of these individuals in one direction in order to carry out a specific function with a purpose. We now add that the work of society is not merely a (spontaneous) agreement among people, ideas and things, but it is the composition of these three social worlds, the composition with which the result of such composition is achieved in its direction and its range of (changing) the faces of life, or more correctly: Developing this society (Bennabi 1986: 27).

The social network is the primary receptacle in which these three realms are developed and combined, so the historical act - or the recording of the idea in history - begins with the formation of the network of social relations and ends with the rupture of this network, regardless of the wealth or poverty of that society with ideas, things and people.

Malik Bennabi says: "When this society - the first Muslim society - entered the course of history in the seventh century, his (realm of ideas) was still a mysterious embryo, if it is measured by the civilized societies it conquered and defeated in Egypt, Persia and Levant. If we look at it when it deteriorated and degenerated six centuries later, we found that it has the richest libraries of the world at the time. It collapsed under the blows of new peoples, such as the Spaniards, whose "realm of ideas" was still relatively poor. Thus, we see that libraries do not reap defeat. The effectiveness of the world of (ideas) is then subject to the network of relations, that is, we can not imagine a homogeneous work of people, ideas and things without these necessary relations. "As the network of relations was closer, the work was effective and influential"( Bennabi 1986: 36)

Therefore, Malik Bennabi explained the hadeeth of the Prophet (peace and blessings of Allah be upon him): «The people will soon summon one another to attack you as people when eating invite others to share their dish. Someone asked: Will that be because of our small numbers

$$
\text { https://doi.org/10.24035/ijit.19.2021.192 }
$$


at that time? He replied: No, you will be numerous at that time: but you will be scum and rubbish like that carried down by a torrent, and Allah will take fear of you from the breasts of your enemy and last enervation into your hearts. Someone asked: What is Wahn (enervation). Messenger of Allah.? He replied: Love of the worldly life and dislike of death. As a kind of evocation of the image of the Muslim world after the rupture of the network of social relations, that is, when it is no longer a community, but just gatherings with no aim like that carried down by a torrent (Bennabi 1986: 40)

\section{Civilization Cycle}

Malik Bennabi developed the "Civilization cycle" model, a model that explains the evolution of societies in the path of the rise and fall of civilization, i.e. the nature of the stages through which a society goes and creates or loses a civilization. These are three, as shown in the following figure: spirit, reason and instinct.

According to Malik Bennabi, the evolution of civilization stages is nothing but evolution in the effectiveness of the religious idea up or down on one hand, and in the effectiveness of the social network expressed by the extent of its cohesion or weariness on the other.

In general, it can be said that "the ideal level of social development that a society can reach depends on the situation under which the society achieves the best temporal psychological conditions to perform its joint activity. This generally occurs when society is in a state of development: Such as the Islamic community in the civil era, and the Christian community in the caves of Rome, as in this case it achieves the highest degree of integration and harmony, the moral tension has reached its peak. The society reaches the final limit in its development when it gradually loses its harmony, its members are scattered like atoms, and at the end of its analysis, it becomes totally incapable of performing its joint activity" (Bennabi 1986: 37)

In the first stage, the stage of the spirit, the religious idea is in the most effective levels, which materializes in the dominance of individuals' behavior, feeling and thought, its ability to control their instincts and the modification of their ethics and relationships, while the social network is in its most intense cases. This quantitatively materializes through the number of social relations among members of the emerging society, and qualitatively takes form based on the quality and depth of such relationships.

At the stage of reason, instincts begin to liberate. "The conflict rages between this desire and the control of spirit. At the same time, the society highlighted by the religious idea continues to develop. And its internal network of connections is completed, as far as the increasing spread of this idea in the world. Therefore, the tangible problems of this new born society arise due to its expansion, and new necessities emerge as a result of its completion." (Bennabi 1986: 71)

At the stage of instinct: Is the stage where the social function of the religious idea ends, so that it becomes unable to carry out its functions of controlling the behavior of the individual and the society and directing it into one goal. Therefore, the powers of society are disintegrated and do not function harmoniously, but individually. Each of which is works for its own benefit, individuality prevails due to the liberation of instincts, and the network of social relations is finally disintegrated (Bennabi 1986: 75) At this stage the society has completed its civilization cycle, and entered into the night of history, even if it is surrounded by a world of ideas, things or people, they do not keep it from the civilization collapse. Malik Bennabi describes this with a sad statement; he says Thus we are in this phase in front of a science inspired by the developing motives of the religious idea and through which the light of civilization emanated. However, if the cycle of civilization ends, the science has been swept away by chaos and turns into nothing. or beneficial knowledge whose learners live in ignorance (Bennabi 1986: 76)

All the above can be expressed in the following figure showing the evolution of the effectiveness of the religious idea and its social network during the stages of civilized development.

$$
\text { https://doi.org/10.24035/ijit.19.2021.192 }
$$


The horizontal axis represents the measure of time, while the vertical axis represents a measure of the psychosocial values that demonstrate the statuses of development:

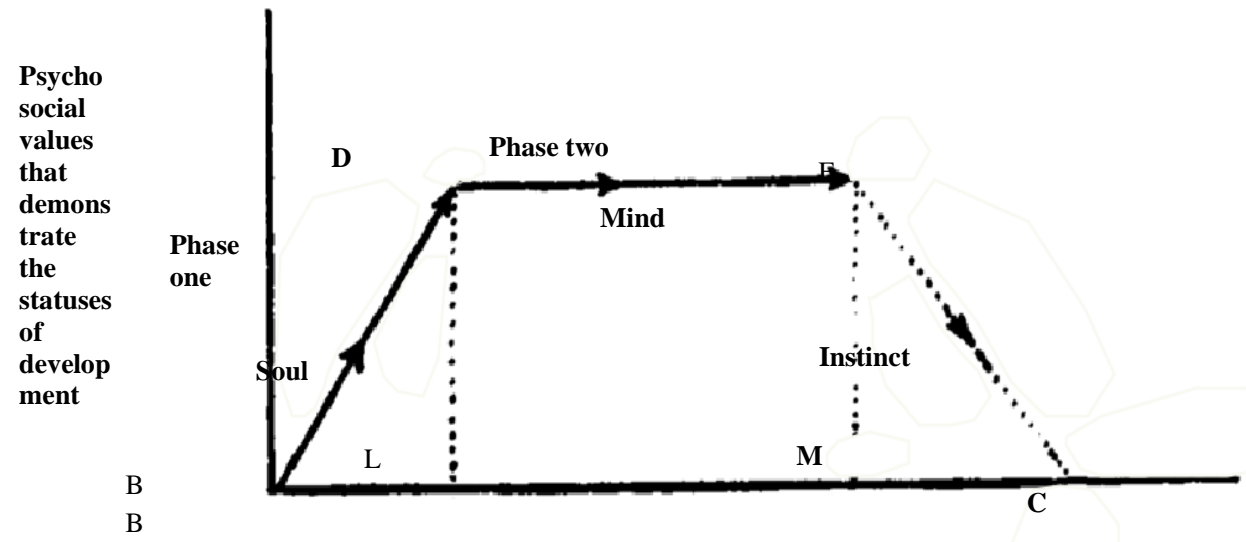

Figure (2) the stages of the development of civilization from the Perspective of Malik Bennabi Source: The Conditions of the Renaissance Book, page 66

To conclude, starting from the fact that civilization is the most important stage of human social development, Malik Bennabi has developed Ibn Khaldun's psychological and sociological analysis to provide a coherent model of how civilizations rise and fall.

Where Malik Bennabi believes that civilizations are born from the religious idea, the worldview or ideology with absolute values, and the birth of civilizations takes place in two stages; The first stage is when the religious or worldview is deepened in the soul through the psychosocial impact of this idea modifying the behavior, feelings and morals of its adherents, leading to the emergence of a new social network. The second stage is when that idea is recorded in history, i.e. once that new network expresses itself in a common collective behavior (for example, the migration incident in Islamic civilization).

Through the network of social relations, the realms of ideas, things and people develop and interact with one another, creating the historical act and creating its events. All societies go through a civilization cycle of rise and fall. The rise starts with dominance of the religious idea on the behavior of individuals and groups begins and a strong and dense network of social relations. The fall takes place when the psychosocial impact of the religious idea disappears, and the network of social relations breaks down.

\section{References}

Acemoglu, D. \& Robinson, J. A. 2013. Why Nations Fail the Origins of Power, Prosperity, and Poverty. London: Profile Books.

Alatas, F. 2013. Ibn Khaldun. New Delhi: Oxford University Press.

Alatas, F. 2015. Applying Ibn Khaldun: The Recovery of a Lost Tradition in Sociology. London: Routledge.

Benlahcene, B. 2011. Malek Bennabis concept and interdisciplinary approach to civilisation. International Journal of Arab Culture, Management and Sustainable Development. 2(1): 55. doi: 10.1504/ijacmsd.2011.044896

Bennabi, M. 1981. Shurut al-Nahzah (The Conditions of the Renaissance). Damascus: Dar al-Fikr.

Bennabi, M. 1986. Milad Mujtama (Birth of Society). Damascus: Dar al-Fikr.

https://doi.org/10.24035/ijit.19.2021.192 
Bennabi, M. 1987. Alzahra al-Quranya (The Quranic Phenomenan). Damascus: Dar al-Fikr.

Bennabi, M. 1991. Qadaya Kubra (Grand Matters). Damascus: Dar al-Fikr.

Buchanan, P. J. 2002. The Death of the West: How Dying Populations and Immigrant Invasions Imperil Our Country and Civilization. New York: Thomas Dunne Books.

Buchanan, P. J. 2012. Suicide of a Superpower: will America Survive to 2025? New York: Thomas Dunne Books.

Diamond, J. M. 2011. Collapse: How Societies Choose to Fail or Succeed. London: Penguin Books.

Ferguson, N. 2010. Complexity and Collapse: Empires on the Edge of Chaos. Foreign Affairs, 89(2), 18-32. www.jstor.org/stable/20699848. Retrieved May 2, 2020, from

Ferguson, N. 2012. Civilization: The West and the Rest. New York: Penguin Press.

Goldman, D. P. 2011. How Civilizations Die. Washington, DC: Regnery Pub.

Kennedy, P. M. 1988. The Rise and Fall of the Great Powers: Economic Change and Military Conflict from 1500 to 2000 00. New York: Random House.

Khaldun Ibn. 2005. The Muqaddimah: An Introduction to History. Princeton, NJ: Princeton University Press.

Spengler, O., \& Atkinson, C. F. 1928. The decline of the West, volume two: perspectives of world history. New York: Alfred A. Knopf.

Toynbee, A. J. 1939. A study of history. London: Oxford University Press.

Weber, M. 1958. The Protestant Ethic and the Spirit of Capitalism: A Classic Study of the Fundamental Relationships Between Religion and the Economic and Social Life in Modern Culture. New York: Scribner. 